\title{
Diversity of a microsatellite locus in the CSN1S1 gene in goat populations raised in the southeastern region of Turkey
}

\author{
Faruk Bozkaya* and Şükrü Gürler \\ Department of Genetics, Faculty of Veterinary Medicine, Harran University, 63300, Sanliurfa, Turkey. \\ Accepted 17 March, 2011
}

\begin{abstract}
The purpose of this study was to investigate the diversity of the microsatellite locus at the CSN1S1 gene in goats raised in southeastern Turkey. DNA was isolated from blood samples collected from goats raised in Kilis $(n=30)$, Sanliurfa $(n=30)$ and Siirt $(n=30)$ provinces of Turkey. The microsatellite locus was amplified using PCR, and fragment lengths of the PCR products were analyzed using a capillary electrophoresis system. Five alleles were found ranging from 206 to $214 \mathrm{bp}$. Observed and expected heterozygosities varied from 0.567 to 0.667 and 0.497 to 0.721 , respectively. Polymorphism information contents and exclusion probabilities varied from 0.462 to 0.668 and 0.289 to 0.466 , respectively. The results suggested that, there were five different alleles of the microsatellite locus of the goat CSN1S1 gene and this microsatellite could be used as a marker for linkage or QTL mapping studies of the goat populations studied.
\end{abstract}

Key words: Goat, microsatellite, polymorphism, diversity, CSN1S1.

\section{INTRODUCTION}

Casein gene polymorphism in goats has been extensively investigated due to the less allergenicity of goat's milk than that of cows (Haenlein, 2004). Therefore, a considerable amount of data on the structure and diversity of casein genes in goat has accumulated in the literature (Cosenza et al., 2008; Ramunno et al., 2005). The structure of the CSN1S1 gene coding for the alfa-S1Casein (as1-Cn) has been studied in detail by several researchers (Jansa-Perez et al., 1994; Ramunno et al., 2005). To date, at least 17 alleles of CSN1S1 gene have been detected. The alleles are characterized by single nucleotide substitutions, and insertions or deletions (Marletta et al., 2007). Ramunno et al. (2005) have

*Corresponding author. E-mail: farukbozkaya@yahoo.com. Tel: +90 4143183911. Fax: +90 4143183922.

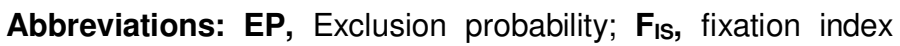
within subpopulations; $\mathbf{F}_{\mathrm{ST}}$, fixation index between subpopulations; STR, simple tandem repeat; QTL, quantitative trait loci; PIC, polymorphism information content. studied the structure of the CSN1S1 gene in goat and detected a simple tandem repeat (STR) of (GT) ${ }_{11-12}$ motive at the $18^{\text {th }}$ intron of this gene. The authors have reported that, the alleles $A$ and $N$ are linked to $(G T)_{11}$ and the allele $F$, is linked to $(G T)_{12}$ motive. Microsatellites or simple tandem repeats (STR) are noncoding DNA fragments with short tandem repeat sequences. Due to their high mutation rates, microsatellites show high polymerphism (Schlötterer, 2000). Microsatellites have been widely used for the examining of population structure (Luikart et al., 1999; Bozkaya et al., 2007), gene and quantitative trait loci (QTL) mapping (Vaiman et al. 1996; Minvielle et al., 2006), and forensic purposes (Nizamlioglu et al., 2006) in different animal species.

No study has been found on the variability of the microsatellite locus in the CSN1S1 gene in goat populations. This microsatellite locus might be used for linkage or QTL mapping due to its known localization in an economically important gene in goat. Therefore, the purpose of this study was to investigate the diversity of the microsatellite locus found in the $18^{\text {th }}$ intron of CSN1S1 gene in three goat populations raised in 
Table 1. Allele frequencies in the three goat populations.

\begin{tabular}{lccccc}
\hline $\begin{array}{c}\text { Allele } \\
(\mathbf{b p})\end{array}$ & $\begin{array}{c}\text { Kilis } \\
(\mathbf{n}=\mathbf{3 0})\end{array}$ & $\begin{array}{c}\text { Siirt } \\
(\mathbf{n}=\mathbf{3 0})\end{array}$ & $\begin{array}{c}\text { Sanliurfa } \\
(\mathbf{n}=\mathbf{3 0})\end{array}$ & $\begin{array}{c}\text { Male } \\
(\mathbf{n}=\mathbf{4 5})\end{array}$ & $\begin{array}{c}\text { Female } \\
(\mathbf{n}=\mathbf{4 5})\end{array}$ \\
\hline 206 & 0.300 & 0.150 & 0.200 & 0.156 & 0.278 \\
208 & 0.267 & 0.683 & 0.367 & 0.444 & 0.433 \\
210 & 0.083 & 0.083 & 0.067 & 0.067 & 0.089 \\
212 & 0.333 & 0.083 & 0.367 & 0.322 & 0.200 \\
214 & 0.017 & 0.000 & 0.000 & 0.011 & 0.000 \\
\hline
\end{tabular}

southeastern region of Turkey.

\section{MATERIALS AND METHODS}

A total of 90 blood samples were collected from goats raised in Kilis $(n=30)$, Sanliurfa $(n=30)$, and Siirt $(n=30)$ provinces of Turkey. Kilis goat has been developed by crossing native hair goats with Aleppo goats and by subsequent interbreeding among the crossbred generations. This goat has been considered a separate breed. Kilis goats are distributed especially in the Kilis province and also raised in the provinces lying along the Syrian border of Turkey. They are kept in small flocks of 2 to 10 goats for particularly milk production. The samples collected from the Sanliurfa province included Aleppo goats, hair goats and the crossbred animals of these two breeds. The samples from the Siirt province included native hair goats and their crossbred animals with Angora goats.

Ten mililiters of blood samples were taken from Vena jugularis by using vacutainers containing EDTA. DNA was isolated using proteinase-K digestion and phenol-chloroform extraction according to Sambrook et al. (1989). DNA samples were measured spectrophotometrically and diluted to an end concentration of $100 \mathrm{ng} / \mu \mathrm{l}$.

PCR was performed by using the following primers: MCN11F (Forward, labeled with FAM) AGTCACATAGTTAAATCAAG and MCN11R (Reverse) AACTTCCAAGTATGTCAGAC. The primers, encompassing the region between 17912th and 18123th nucleotides, were designed on the basis of the sequence (Accession No: AJ504710) submitted to GeneBank by Ramunno et al. (2005). PCR was carried out in $25 \mu$ volume containing: $100 \mathrm{ng}$ of genomic DNA, 10 pmol of each primer, dNTPs each $0.2 \mathrm{mM}$, $1.25 \mathrm{U}$ of Taq DNA polymerase (Fermentas, Vilnius, Lithuania), 3 $\mathrm{mM} \mathrm{MgCl} 2$ and $2.5 \mu \mathrm{l}$ of $10 \mathrm{X}$ reaction buffer contained $100 \mathrm{mM}$ Tris$\mathrm{HCl}(\mathrm{pH} 8.8) 500 \mathrm{mM} \mathrm{KCl}$ and $0.8 \%$ Nonidet P40. The amplification protocol consisted of an initial denaturing step of $94^{\circ} \mathrm{C}$ for $5 \mathrm{~min}$, followed by 10 cycles of $94^{\circ} \mathrm{C}$ for $30 \mathrm{~s}, 60^{\circ} \mathrm{C}$ for $30 \mathrm{~s}$ decreasing $1{ }^{\circ} \mathrm{C}$ in each cycle and $72{ }^{\circ} \mathrm{C}$ for $30 \mathrm{~s}$ and 25 cycles of $94^{\circ} \mathrm{C}$ for $30 \mathrm{~s}$, $50^{\circ} \mathrm{C}$ for $30 \mathrm{~s}, 72^{\circ} \mathrm{C}$ for $30 \mathrm{~s}$. In the final cycle, the extension step was carried out at $72^{\circ} \mathrm{C}$ for $10 \mathrm{~min}$.

The PCR products were analyzed for their fragment lengths by means of a capillary electrophoresis system (Applied Biosystems, 3130xl Genetic Analyzer, Foster City CA). For detecting the alleles, peak scanner software v1.0 (Applied Biosystems) was used.

Allele frequencies, observed and expected heterozygosities, Hardy-Weinberg probabilities (Guo and Thompson, 1992), inbreeding coefficients $\left(F_{I S}\right)$ for heterozygote deficiency, $F_{S T}$ genetic distances (Weir and Cockerham, 1984) and population differentiations (Raymond and Rousset, 1995a) were calculated using the GENEPOP package, Version 3.1 (Raymond and Rousset, 1995b). Nei's (1972) genetic distances between populations were calculated by using the GenAIEx.6 package (Peakall and Smouse, 2006). Polymorphism information contents (PIC) were computed using the formula of Botstein et al. (1980). The exclusion probability (EP) for the case, where one parent is known was estimated using the general formula 1 a from Jamison and Taylor (1997).

The study was carried out with the permission of Harran University Animal Experimentation Local Ethics Committee.

\section{RESULTS AND DISCUSSION}

All samples were successfully amplified by using the designed primers and PCR method. The microsatellite locus was polymorphic in all three populations studied. Allele frequencies and parameters estimated for the locus in the three goat populations studied were shown in Tables 1 and 2, respectively. A total of five different alleles of fragment lengths ranging from 206 to $214 \mathrm{bp}$ were found. Only the allele of $214 \mathrm{bp}$ fragment length was specific to Kilis goats and carried by an individual. The most common allele was 212 bp in this population. Expected heterozygosities varied between 0.497 and 0.721 and PIC values ranged from 0.462 to 0.668 . Observed and expected genotype frequencies did not differ in the three populations studied. Siirt population was found to be significantly differentiated from Sanliurfa and Kilis populations $(p<0.001)$, while the differentiation between Kilis and Sanliurfa populations was not significant $(p>0.05)$. The smallest genetic distance was observed between Kilis and Sanliurfa populations for both Nei's (1972) genetic distances and F $F_{S T}$ values (Weir and Cockerham, 1984).

To our knowledge, this is the first report on the diversity of the microsatellite locus in the goat's CSN1S1 gene. Therefore, the results of this study could only be compared with those from other microsatellite loci.

The sample size (30 for each population) used in this study was in accordance with those reported by Luikart et al. (1999) and Canon et al. (2006), who have used 28 to 32 and 29 to 62 samples per breed, respectively. The samples were collected from 37 different herds and therefore, representative for the populations studied.

The allele number $(\mathrm{Na}=5)$ observed at the microsatellite locus in this study was in general lower than that found for other microsatellite loci in different goat populations. For instance, Saitbekova et al. (1999) observed in Swiss goat breeds 12 and 19 alleles at the 
Table 2. Population parameters of the three goat populations.

\begin{tabular}{lccccc}
\hline \multirow{2}{*}{ Parameter } & \multicolumn{5}{c}{ Population } \\
\cline { 2 - 6 } & $(\mathbf{n = 3 0})$ & $\begin{array}{c}\text { Siirt } \\
(\mathbf{n}=\mathbf{3 0})\end{array}$ & $\begin{array}{c}\text { Sanliurfa } \\
(\mathbf{n}=\mathbf{3 0})\end{array}$ & $\begin{array}{c}\text { Male } \\
(\mathbf{n}=\mathbf{4 5})\end{array}$ & $\begin{array}{c}\text { Female } \\
(\mathbf{n}=\mathbf{4 5})\end{array}$ \\
\hline $\mathrm{Na}$ & 5 & 4 & 4 & 5 & 4 \\
$\mathrm{Ne}$ & 3.58 & 1.99 & 3.32 & 3.029 & 3.197 \\
$\mathrm{Ho}$ & 0.667 & 0.567 & 0.600 & 0.556 & 0.667 \\
$\mathrm{He}$ & 0.721 & 0.497 & 0.687 & 0.670 & 0.687 \\
$\mathrm{~F}$ & 0.075 & -0.141 & 0.126 & 0.171 & 0.030 \\
$\mathrm{PIC}$ & 0.668 & 0.462 & 0.626 & & \\
$\mathrm{EP}$ & 0.466 & 0.289 & 0.431 & & \\
\hline
\end{tabular}

$\mathrm{Na}$, Number of alleles; $\mathrm{Ne}$, effective number of alleles; Ho, observed heterozygosity; He, observed heterozygosity; $F_{I S}$, fixation index; PIC, polymorphism information content; EP, exclusion probability.

INRABERN175 and ILSTS30 loci, respectively. Bozkaya et al. (2007) found 14 and 15 alleles for the DYMS1 and BM1258 loci in Turkish goat breeds, respectively. The number of alleles observed in different populations at the microsatellite loci MAF65 and MAF70 varied from 12 to 24 and from 16 to 17, respectively (Li et al., 2002; Canon et al., 2006). However, there were also a number of loci with allele numbers similar to that analyzed in the present study. The number of alleles observed for BF, ILSTS005, MAF209, SRCRSP3, INRA005, ILSTS059, ETH10 and INRA037 varied from three to five (Luikart et al., 1999; Saitbekova et al., 1999; Bozkaya et al., 2007). The differences observed in the number of alleles might result from the locus or populations under consideration. For instance, the number of alleles observed at OarAE54 and SRCRSP5 loci was five in Saanen breed, while it was ten in Mongolian Cashmere (Luikart et al., 1999). Therefore, further studies are necessary for detecting new alleles at this locus in different goat populations.

The mean expected heterozygosity found for the locus studied $(0.635)$ was lower than that $(0.690)$ reported by Canon et al. (2006), who studied 45 goat populations by using 30 microsatellite loci, while it was similar to that (0.611) found by Luikart et al. (1999), who have studied four goat populations by using 22 microsatellite loci. The higher value found by Canon et al. (2006) might be due to the loci studied, which have been selected for their high polymorphism in order to study genetic structures of populations. The value found for the locus studied was indeed higher than that reported by these authors for the loci MAF209 (0.255 to 0.260), ILSTS005 (0.523 to go0.524), SRCRSP3 (0.462 to 0.525) and ETH10 (0.560 to 0.570 ), with similar allele numbers as the locus in this study (Luikart et al., 1999; Canon et al., 2006). The PIC values in Kilis (0.668), Sanliurfa (0.626) and Siirt (0.462) populations were generally higher than or similar to those reported by Luikart et al. (1999) for the loci MAF209
(0.086 to 0.353 ), ILSTS005 (0.114 to 0.369 ), SRCRSP3 (0.404 to 0.585$)$ and ETH10 (0.377 to 0.639). Loci with PIC values over 0.5 have been considered highly informative by Botstein et al. (1980).

Siirt population was found to be significantly differentiated from Sanliurfa and Kilis population $(p<0.001)$, while the differentiation between Kilis and Sanliurfa populations was not significant $(p>0.05)$. In accordance with this finding, the genetic distance between Kilis and Sanliurfa populations was smaller than that between Siirt and these two populations. The results might be due to smaller geographic distance between Kilis goats and Sanliurfa goat population. Kilis goats have been developed by crossing native hair goats with Aleppo goats and by subsequent interbreeding among the crossbred generations. Kilis goats have been considered a separate breed (Yalcin, 1986). The Sanliurfa goat population consisted of individuals with both the phenotype of Aleppo goats and hair goats. Therefore, it is reasonable to suggest that, Kilis and Sanliurfa goat populations have a similar gene pool. However, Barker (1994) suggested that, for genetic distance studies, microsatellite loci should have more than four alleles to reduce the standard errors of distance estimates. Therefore, the number of the marker and the sample size used in this study was not sufficient to suggest that these two populations would be considered subpopulations of the same breed. Polymorphic and informative loci should be used in order to better estimate the genetic relationship between Kilis goats and Sanliurfa populations.

The results of the study have suggested that, there were at least five different alleles of the microsatellite locus located in the CSN1S1 gene in goat populations studied. Further alleles can be found in different populations. Polymorphism information content values found in the present study suggested that, this locus could be used for further linkage or QTL mapping efforts in the 


\section{populations studied.}

\section{REFERENCES}

Barker JSF (1994). A global protocol for determining genetic distances among domestic livestock breeds. In: Proc. of the 5thWorld Congress on Genetics Applied to Livestock Production, 7-12 August 2000, Vol. 21, University of Guelph, Ontario, pp. 501-508.

Botstein D, White RL, Skolnick M, Davis RW (1980). Construction of a genetic linkage map in man using Restrication Fragment Length Polymorphisms. Am. J. Hum. Genet. 32: 314-331.

Bozkaya F, Kuss AW, Geldermann H (2007). DNA variants of the MHC show location-specific convergence between sheep, goat and cattle. Small Rumin. Res. 70: 174-182.

Canon J, Garcia D, Garcia-Atance MA, Obexer-Ruff G, Lenstra JA, Ajmone-Marsan P, Dunner S, The Econogene Consortium (2006). Geographical partitioning of goat diversity in Europe and the Middle East. Anim. Genet. 37: 327-334.

Cosenza G, Paciullo A, Colimono L, D'Avino A, Mancusi A, Ramunno L (2008). Genotyping at the CSN1S1 locus by PCR-RFLP and AS-PCR in a Neapolitan goat population. Small Rumin. Res. 74: 84-90.

Guo SW, Thompson EA (1992). Performing the exact test of HardyWeinberg proportion for multiple alleles. Biometrics, 48: 361-372.

Haenlein GFW (2004). Goat milk in human nutrition. Small Rumin. Res. 51: 155-163.

Jamison A, Taylor StCS (1997). Comparisons of three probability formulae for parentage exclusion. Anim. Genet. 28: 397-400.

Jansa-Perez M, Leroux C, Sanchez A, Martin P (1994). Occurrence of a LINE sequence in the 3' UTR of the goat as 1-casein E- encoding allele associated with reduced protein synthesis level. Gene, 147: 179-187.

Li MH, Zhao SH, Bian C, Wang HS, Wei HI, Liu B, Yu M, Fan B, Chen SL, Zhu MJ, Li SJ (2002). Genetic relationships among twelve Chinese indigenous goat populations based on microsatellite analysis. Genet. Sel. Evol. 34: 729-744.

Luikart G, Buji-Duval MP, Ertugrul O, Zagdsuren Y, Maudet C, Taberlet $P$ (1999). Power of 22 microsatellite markers in fluorescent multiplexes for parentage testing in goats (Capra hircus). Anim. Genet. 30: 431-438.
Marletta D, Criscione A, Bordonaro S, Guastella AM, D'Urso G (2007). Casein polymorphism in goat's milk. Lait, 87: 491-504.

Minvielle F, Kayang BB, Inoue-Murayama M, Miwa M, Vignal A, Gourichon D, Neau A, Monvoisin JL, Ito S (2006). Search for QTL affecting the shape of the egg laying curve of the Japanese quail. BMC Genet. 7: p. 26.

Nei M (1972). Genetic distance between populations. Am. Nat. 106: 283-392.

Nizamlioglu M, Kurar E, Bulut Z, Inal S, Erzurum F (2006). Microsatellite analysis of some horse breeds in Turkey: usefulness for parentage testing. FEBS J. 273: 365-366.

Peakall R, Smouse PE (2006). GENALEX 6: genetic analysis in Excel. Population genetic software for teaching and research. Mol. Ecol. Notes, 6: 288-295.

Ramunno L, Cosenza G, Rando A, Pauciullo A, Illario R, Gallo D, Berardino D, Masina $P$ (2005). Comparative analysis of gene sequence of goat CSN1S1 $\mathrm{F}$ and $\mathrm{N}$ allele and characterization of CSN1S1 transcript variants in mammary gland. Gene, 345: 289-299.

Raymond M, Rousset F (1995a). An exact test for population differentiation. Evolution, 49: 1280-1283.

Raymond M, Rousset F (1995b). GENEPOP (Version 1.2): Population genetics software for exact tests and ecumenism. J. Heredity, 86: 248-249.

Saitbekova D, Gaillard C, Obexer-Ruf G, Dolf G (1999). Genetic diversity in Swiss goat breeds on microsatellite analysis. Anim. Genet. 30: 36-41

Sambrook J, Fritsch EF, Maniatis, T (1989). Molecular Cloning- A Laboratory Manual. Cold Spring Harbor Laboratory Press, New York, USA.

Schlötterer C (2000). Evolutionary dynamics of microsatellite DNA. Chromosoma, 109: 365-371.

Vaiman D, Schibler L, Bourgeois F, Oustry A, Amiguest Y, Cribiu EP (1996). A genetic linkage map of the male goat genome. Genetics, 144: 279-305.

Weir BS, Cockerham CC (1984). Estimating F-statistics for the analyzing population structure. Evolution, 38: 1358-1370

Yalcin BC (1986). Sheep and goats in Turkey. FAO Animal Production and Health Paper 60. Food and Agriculture Organization of the United Nations, Rome. 